This is a self-archived - parallel published version of this article in the publication archive of the University of Vaasa. It might differ from the original.

\title{
Participative policymaking in complex welfare system : a Delphi study
}

Author(s): Pernaa, Hanna-Kaisa

Title: $\quad$ Participative policymaking in complex welfare system : a Delphi study

Year: $\quad 2020$

Version: Final draft (post print, aam, accepted manuscript)

Copyright C)2020 Springer Nature Singapore Pte Ltd. This is a post-peer-review, pre-copyedit version of an article published in Lehtimäki, H., Uusikylä, P., \& Smedlund, A. (eds). Society as an interaction space : a systemic approach. Springer. The final authenticated version is available online at: https://doi.org/10.1007/978-981-15-0069-5.

Please cite the original version:

Pernaa, H.-K., (2020). Participative policymaking in complex welfare system : a Delphi study . In: Lehtimäki, H., Uusikylä, P., \& Smedlund, A. (eds). Society as an interaction space : a systemic approach (pp. 109132). Springer. https://doi.org/10.1007/978-981-15-0069-5 
Participative policymaking in complex welfare system - a Delphi study

Hanna-Kaisa Pernaa

Doctoral student

School of Management

University of Vaasa

hanna-kaisa.pernaa@uva.fi

\begin{abstract}
Shared, experience driven and value based perspectives in an ongoing interaction of agents constitute the basis of the co-evolutionary dynamic of a complex system. The interpretation of good governance comprehends participation as increasingly fundamental in approaching policies in complex systems. This chapter presents a Delphi-study of the possibilities and obstacles of participative policymaking (PPM) in municipal welfare services viewed by an expert panel consisting of 37 participants representing the executive managers of $3^{\text {rd }}$ sector organizations, the chairmen of the municipal councils or welfare service boards and the leading office-holders of municipal welfare offices in Finland. The panel estimated and discussed the projections of participatory welfare policy making in 2030. The outcomes of the study indicate that regardless of technological preparedness and the structural opportunities offered by a reform, cultural inertia and unawareness generate attitudes inhibitory on PPM practices. Albeit participative practices were considered influential to policymaking legitimacy as well as central to the nature of equal and flexible resource distribution, there were reservations about the inclusion of the participation. There were concerns over the validity and the liability of the decisions reached by participative means. Several undercurrents affecting the development of PPM were discernible in the conversations.
\end{abstract}

\title{
Introduction
}

Shared, experience driven and value based perspectives in an ongoing interaction of agents constitute the basis of the co-evolutionary dynamic of a complex system. The ability to review and challenge the validity of a policy by various stakeholders requires a novel mindset of the policymaking process. (McGlade \& Garnsey, 2006, pp. 10-12; Boulton, Allen \& Bowman, 2015, pp. 212-214, 219). Engaging the public in the ownership of policymaking processes has shaped the public administrative theories (e.g. Puyn \& Gamassou, 2017) and policymaking practices towards enabling co-evolutionary practices (Mitleton-Kelly, 2011b). In the welfare service context, the small marginal group of large-scale service consumers (see Perttola \& Pernaa, 2016) should be of considerable relevance in the comprehension of the systemic policy influences. Yet although widely approved, the citizen participation in policymaking processes is developing at slow pace (Raisio 2010; Möttönen 2012; Monno \& Khakee, 2012). 
This chapter presents a Delphi study of the future of participative policy-making development in Finnish public welfare services, viewed by an expert panel consisting of 37 participants representing the executive managers of third sector organizations, the chairmen of the municipal councils or welfare service boards and the leading office-holders of municipal welfare offices. The panel estimated and discussed the projections of participatory welfare policy making in 2030. The majority of research focused on the citizen engagement takes place in organizations and networks (Nabatchi, 2012), usually with an objective to elucidate the variety of participative practices. This case study presents an untypical yet significant, policymaking experts' perspective to the unspoken inertia in the construction of civic engagement culture in policymaking practices. With respect to the fact of any model's inability to offer a comprehensive description of a complex system, this study provides examination and illumination of the prospects, incentives, impediments and undercurrents affecting the participatory development in Finnish welfare service policymaking. The main result of the study can be formulated as a contradiction between the complex systems' ability to create new order and the inability of polity to recast the social policies to be more responsive to the changing societal demands.

The chapter begins by describing the welfare service system complexity and the significance of the participative societal advocacy in the complex system co-evolution and further, in the context of welfare policymaking. The introduction of the Delphi research method and the study description is followed by an outline of the study process and the discussion of the results.

\section{Welfare services as complex systems}

Perceiving complexity sciences as a contributing field and complexity as a constituent part of policy processes is gaining ground in public administrative discourse (Eppel, 2012; 2017). Any public administrative entity can be perceived as a complex social system with several levels, layers and clusters each composed of individuals with social interrelations. Even if the features of a single, interacting part contributes to the entity of a complex system, it cannot be scrutinized merely by its parts. A change in any part of the system does not indicate a linear and predictable outcome, but a variety of repercussions. (Eppel, 2017; Byrne, 2001, p. 14.) This "entanglement" of numerous elements and individuals enables creativity and dynamics and furthermore, mutual dependence even between organizations and their environments. (Haynes, 2015, p. 19.)

Understanding the parts of a system as components of the whole emphasizes the comprehension of their integration and mutual relationships (Capra \& Luisi, 2014, pp.63-64; 80-81). Welfare services ${ }^{1}$ have an indirect relationship with political choices by bidirectional implications for national economy (e.g. Pierson, 2000; Seaford 2014) and more directly, the salutogenic ${ }^{2}$ assets for individual health and well-being. Put in a complex entity of people with a varying scope of personal and subjective needs, welfare services can be

\footnotetext{
${ }^{1}$ In this study, 'welfare' is understood in its widest sense, referring to the well-being of the citizens and 'welfare services' as a collective service provision to enhance it.

2 The concept introduced by medical sociologist Aaron Antonovsky portrays the human "abilities and resources to develop positively", underlining the societal arrangements to utilize those capabilities (Eriksson \& Lindström 2014).
} 
understood and evaluated normatively on the basis set by independent welfare policies and their efficacy - or impotence - of prevailing societal conditions. (Spicker, 2008, pp. 17-36.)

The association of policymaking and knowledge utilisation in public administration has transformed from the rational, information-based decisions to using the knowledge for the understanding and steering of complex realities (Parsons, 2004) and to recognizing the interdependencies of economic, societal and environmental policies (Adams \& Wiseman, 2003; Boulton, Allen \& Bowman, 2015, pp. 212-213). As a result of this development, the public policymaking and governance requires progress from "apparent simplicity and rationality" of the bureaucratic and market rationalism, towards "balance, accountability and engagement in complex policy environments" (ibid., p. 22).

The perception of a successful change in any human, complex system is one carried out by shifting of the approach from structures to processes (Capra \& Luisi, 2014, p. 81) and consequently appreciating and enabling the equal interplay between different dimensions and levels of interaction within the system (Goergen, Mallin, Mitleton-Kelly, Al-Hawamdeh \& Chiu, 2010, pp. 4-5). It is also intrinsic to its characteristics: the emergence of new phenomena arising from the connectivity and at the same time, the ability to create new order. The multiple layers of the underlying and sometimes implicit causes of problem spaces take place contextually. The same also holds true for appropriate means of addressing issues distinctive to a particular system. Instead of seeking an all-embracing solution to several, sometimes overlapping issues, the primary administrative objective should be fostering an adaptable and enabling environment for co-evolution. (Goergen et.al., 2010, pp. 4-22.)

\section{Co-evolution claims participation}

Due to the anti-reductionist nature - the inability to analyse a complex system by examining its parts - evolution and holism, the two major components of complexity, are inseparable (Byrne, 2001, p. 15). Societies seen from complexity perspective are in continuous evolution with emerging and changing dynamics, political and ideological movements and by - hopefully - learning from them. The process of choosing our societal objectives and our mutual interactions accordingly become essential in the state of flux and proliferating uncertainty. Even if the increasing amount of data enhances the knowledge and awareness of interconnectedness in complex issues, it does not exclude ethical and moral discourse. The effect is emphasized in globally paramount issues, such as global warming. Scientific approach is essential but calls for extensive engagement in the process of creating ethical and justifiable policies. (Mannermaa, 1988; Dennard, Richardson \& Morçöl, 2008; Collins 2010).

It is characteristic of any complex, human system to have multiple and interrelated challenges with several dimensions and ways to address them. This becomes emphasized in decision making and in fundamental systemic changes. The true respect of the complex, interactive dimensions affecting a problem-space requires engaging the problem owners in its examination. (Mitleton-Kelly, 2011a.) Accumulating the data and 
multifaceted elucidations of policy issues is a prerequisite for adapting them to local circumstances, to learn from them, as well as to create communal resilience (Boulton, Allen \& Bowman, 2015, p. 219). The general interest for lay participation in public policymaking has been increasing since the 1990's, simultaneously with the declining trust for political and societal institutions in the advanced western societies. The phenomenon coincides with the proliferating knowledge available for public, rise in educational levels as well as the value shift from maximizing the economic wealth to the enhancing of subjective well-being. (Inglehart, 1999.)

Even if the scopes of the complex issues can be comprehended to some extent, the means of addressing them can neither be definitive nor static. A creative and enabling environment for change promotion in a complex system has stated to be robust only along with co-evolutionary qualities of its own. (Goergen et al., 2010, p. 5; Mitleton-Kelly, 2011a.) Considering a variety of societal and even global issues, nongovernment organisations are found significant in initiating public engagement processes. In addition to the strong involvement of third sector organised stakeholder groups, an even larger portion of actors of innovative public engagement comes from a fourth sector, "actors or actor groups whose foundational logic is not in the representation of established interest, but rather, in the idea of social cooperation through hybrid networking". (Rask et al. 2016, p.3.) While this phenomenon of proactive, self-organizing and emergent activism is mostly not acknowledged as a constituent element of societal activism, it is gaining ground on participative dynamics (Rask, Puustinen \& Raisio, 2018).

The demands for participative societal advocacy have shaped the public administrative bodies and practices by means of institutional innovations. (Atkinson, 2002; Warren, 2009). Viewed in general, the phenomena of enhancing the civic engagement can be anticipated to expand further, beyond the domains of direct democracy and governance into more extensive discourse in scientific issues with societal and environmental impact (e.g. Köhler et al., 2015; Pernaa, 2017; Blue, 2018). An inevitable transformation of civil advocacy is acknowledged and included in the frameworks in various European programs in the ongoing process of "aligning research and innovation to the values, needs and expectations of European society" (RRI 2014; Euroscientist, 2016).

\section{The welfare policy participation}

Welfare policymaking requires acknowledging the system as an entity of interacting systems and further, as a co-evolving and transforming ecosystem. The understanding of this interaction elucidates its consequences and changes the administrative foci to enabling the interaction and developing the discourse competency. (Kernick, 2008.) The public administrative exploration of the welfare service systems traditionally emphasizes the internal structures and interrelation between the variety of service providers. The main theories of the public administration have all added their heterogenous characteristics in examining welfare systems, whether the subject has been a national or an organisational reform or any other objective to foster the public good. According to Puyn and Gamassou (2017) the trajectory of the theories from theoretical and practical 
predominance to public participation in decision-making indicates a societal desire to "getting back to the traditional values, that's to say, the general welfare and the social harmony" (p. 255). The trend is considered having gained strength in western societies by experiences of the Arab Spring and the development of electronic administrative applications.

Longitudinal studies in health care organisations have shown the distinctive characteristic of complex systems to strive for sustainability by creating new order through enabling co-evolutionary processes (Mitleton-Kelly, 2011b.) Put in a national welfare service system context, the challenge of changing the policy inertia is demanding due to its "lock in effect". In order for a reform to take place the incentives have to overcome strong resistance by not only an institutional, but also public path dependency. More daring the intended change and its consequences to the systems arrangements are, the more likely it is preceded by a severe political and/or economic crisis. (Hemerijck, 2002.) In retrospect, a "crisis" represents the lead-up to the turning point where the transformation of a complex system occurs. The previous state is unattainable due to the developments in causal and underlying, structural nexuses. (Byrne, 2001, p. 151). Complexity sciences aim to examine the instability, self-organizing capacities and emergent behaviour below the apparent macro level or long term stability, causing - if gaining a critical mass of significance - greater changes (Mitleton-Kelly, 2003; Haynes, 2015, p. 43; Cairney 2012).

Any policy addressing the future of a society is tinged with expectations, emotions and assumptions originating from its culture and history. The designated values based objectives of a policy can therefore not be attained by solely evidence-based nor archived information. The core of the policy aspiration should consist of the public conceptions, even subjective, of the factors contributing to the present state. (Appadurai, 2013, pp. 286-289.) In the context of welfare policies, the accentuation of the subjective perceptions should be of the deviant, vulnerable and marginal groups (Raisio, Valkama \& Peltola, 2014) that can also be considered as large-scale consumers of the welfare services (Perttola \& Pernaa, 2016). Welfare service organizations are balancing between their tolerant, customer-oriented values and a strain of efficacy and simultaneously, not only smooth away deviant voices but "assume the right to define and diagnose normality and deviance" (Riikonen, Makkonen \& Smith, p. 312).

The discrepancy between increasing demands of welfare services and diminishing fiscal resources calls for the policy principles implemented by the variety of domestic welfare services to be sensitive and adjustable with reference to the evidence of services beneficial to general well-being (Seaford 2014; Hemerijck, 2002). Given the complexity and multiple dimensions of a welfare system with an extensive sphere of intergenerational influences, the necessary service rationalisations cannot be tackled by focusing on the structural dimension only (see Mitleton-Kelly 2011b). An inadequate recognition of health care complexity during a reform process can result in implementing linear and deficient solutions (Raisio 2009) and thereby, unsuccessful outcomes (Vartiainen 2005). 


\section{Case Finland: the description of the study}

The extensive efforts to rearrange welfare services in Finland highlight the desideratum of participative policymaking (PPM) discussion. By restructuring the municipal and regional duties - to enhance the wellbeing of the citizens and to reduce inequalities in health and well-being - the arrangement of and relations between welfare branches, different public entities, NGO's and private health care service providers create a multisectoral realignment where the perception of service users should not be ignored.

Finnish social and welfare services are slowly comprehending the importance of service users' expertise in developing the services to advance the well-being, and the ways of the citizens' consultancy are taking shape slowly (Raisio 2010; Möttönen 2012). Despite the efforts of Finnish ministries and public offices in developing citizens' engagement and municipal democracy (e.g. Ministry of Finance, 2017; 2018) the experiments in participative policymaking have remained local and relatively small-scale.

The purpose of the study was to discover and discuss the possibilities of addressing the challenges of welfare service complexity by participatory ${ }^{3}$ instruments, involving the residents and service users in the municipal welfare policymaking. The study aimed at deepening the comprehension of the incentives and impediments affecting the participatory policymaking development in the welfare service ecosystem, by providing insight into the perceptions of experienced municipal policymakers ${ }^{4}$ and the administrators of nongovernmental welfare organizations.

The research questions of the study were:

- Which factors are considered as fundamental to the participative welfare policymaking development in Finland?

- What are the undercurrents of the protracted development in participative welfare policymaking?

The study located temporally in a critical juncture of an extensive Finnish regional government, health and social service reform ${ }^{5}$. The reform originated from the 2004 PARAS- reform to restructure municipalities and services, which paved the way to the current, comprehensive social welfare and health care reform with an aim of the "equal provision of social welfare and health care services" (THL, 2019). During the first week of the study in November 2015, the Ministry of Social Affairs and Health and the Ministry of Finance gave a significant outline for the service arranging responsibility to be transferred to the self-governing regions, wider than the present municipalities. Simultaneously, the current financing and the welfare service provision system would be rearranged. The timing served the study by offering a tabula rasa for the experts to consider

\footnotetext{
${ }^{3}$ In this study, the concept of participation implies the desire to influence in welfare policies by a variety of participative practices.

${ }^{4}$ The municipal policymaking in Finland is presently built on the so-called "dual model", local councilors making decisions based on proposals and details prepared by the office-bearers.

${ }^{5}$ Due to the resignation of the Government at the time, the preparations for the implementation of the reform were discontinued in March 2019.
} 
the future of the Finnish welfare services without clear vision of the inchoate reform and yet, with an awareness of inevitable and significant changes in the financing and administrative structure of the welfare services.

The study was implemented as a web-based Delphi-study in October-December 2015 in three rounds, each active for two weeks. The analyses of the rounds were conducted within a week between them. The survey was built of future claims, which were anonymously assessed and commented by experts (henceforth referred to as panelists). The expert panel consisted of 37 participants, representing Finnish

- representative chairpersons of the municipal councils/welfare service boards;

- leading municipal welfare department office-bearers, and

- executive managers of the third sector welfare organizations

The panelists representing the municipal electives and officials were chosen with a random sampling from the statistics ${ }^{6}$ provided by the Association of Finnish Local and Regional Authorities (Kuntaliitto, n.d.). The panelists representing the third sector welfare organizations were chosen with a random sampling from the statistics ${ }^{7}$ provided by SOSTE, the Finnish federation for social affairs and health, an umbrella organization of 200 welfare NGO's. All of the selected panelists held a responsible position in their background institutions, with an assumption of considerable experience in welfare policymaking practices and/or welfare service user perspectives.

50 candidates were approached by e-mail, including a brief introduction to the study as well as the date and time for a more informative telephone discussion. During the second approach by telephone further details of the study were discussed and a total of 47 experts - consisting of 15 NGO representatives, 14 municipal chairs and 18 municipal officials - gave an approving response to participation. From the original group the amount of 37 experts were actively engaged in the study, with a varying degree of activity in its different parts, as well as in different claims.

The study was fully anonymous, enabling the participants to express their views as private individuals, free from organizational representativeness and group dynamics. To secure the anonymity, the panelists representing political decision-makers and office-bearers were selected from different municipals with no announced, cooperative affiliations or consolidations.

\section{The Delphi method}

The Delphi method has its origins in 1950's war strategic research. The method was originally developed by the RAND Corporation for forecasting trends and complex problems by the experts of different fields to anticipate the changes in post-war Europe (Dalkey \& Helmer, 1963). Futurist Harold A. Linstone and physicist Murray Turoff have stated an extensive description of it $(1975,3)$ : “[Delphi is] a method for structuring

\footnotetext{
${ }^{6}$ At the time of the study, Finland consisted of 317 municipalities.

${ }^{7}$ At the time of the study, a total of 200 NGOs was listed under the parent organisation SOSTE.
} 
a group communication process so that the process is effective in allowing a group of individuals, as a whole, to deal with a complex problem." Delphi method and its modifications using the wisdom of crowds (Hiltunen, 2011) have been widespread and accepted ${ }^{8}$ not only among foresight practices but more widely as a technique in scientific research and decision-making support.

The special characters of the method can be identified as anonymity, expertise knowledge and iteration. In a Delphi process, the experts of various fields are brought together to deliberate a current, controversial question. The experts are asked to judge and argue the probability and desirability of future claims (Linturi \& Rubin, 2014) and conducted to an anonymous, written discourse on the subject, characterized by expertise instead of status or authority. The iteration is achieved by returning the analyzed results to the panelists, who are guided further to re-evaluate, argue or justify their assessments. Previous round forming a base for the next one results in a dialogue that aims to confront expert disputes without confrontation and to examine standpoints not necessarily supported by oneself. (Linturi 2007; Kuusi 2002.)

Linstone and Turoff (1975) have identified issues that can be effectively addressed by the method. Concerning public administration and wellbeing, following attributes can be emphasized (Ziglio 1996):

- issues not suitable for explicit analyzing techniques, but benefit from evaluations based on collective, subjective analysis;

- issues without "monitored" history or sufficient information of its present state, nor future development;

- $\quad$ issues that require multiple approaches in evaluating different policies.

The study required an online platform for an anonymous discourse, with the ability to transform the data to be used in software applications for the analyses (in this study, SPSS and NVivo). The Delphi method and the open-source software eDelfoi ${ }^{9}$ met the requirements of the study. The construction of the study began in May 2015, concurrently with method training and monthly workshops offered by the Finnish administrative and developing network of the software.

\section{The first round of the study: construction}

The flow chart (Figure 1.) describes the study process of the 3-round, modified Delphi. The first round (R1) of a Delphi is commonly constructed by the panelists involved in the study, to generate a frame of reference to be used in the following rounds. In this study, to offer a comprehensive basis for an examination of an issue inevitably generating controversies, the early framing of the discussion consisted of predetermined, theory-based (described below) perspectives which were then assessed by the expert panel.

\footnotetext{
${ }^{8}$ For a description of the Delphi method stages of development, see Rieger, 1986.

${ }^{9}$ Current version, eDelphi, is a third version of a web-based software, introduced in late 90's by a corporation of Finnish futures scientists Linturi, Kuusi and Kaivo-oja. "eDelphi has been developed during 20 years together with Finnish future research institutions including University of Turku Futures Research Centre and Society for Futures Research” (http://www.edelphi.org).
} 


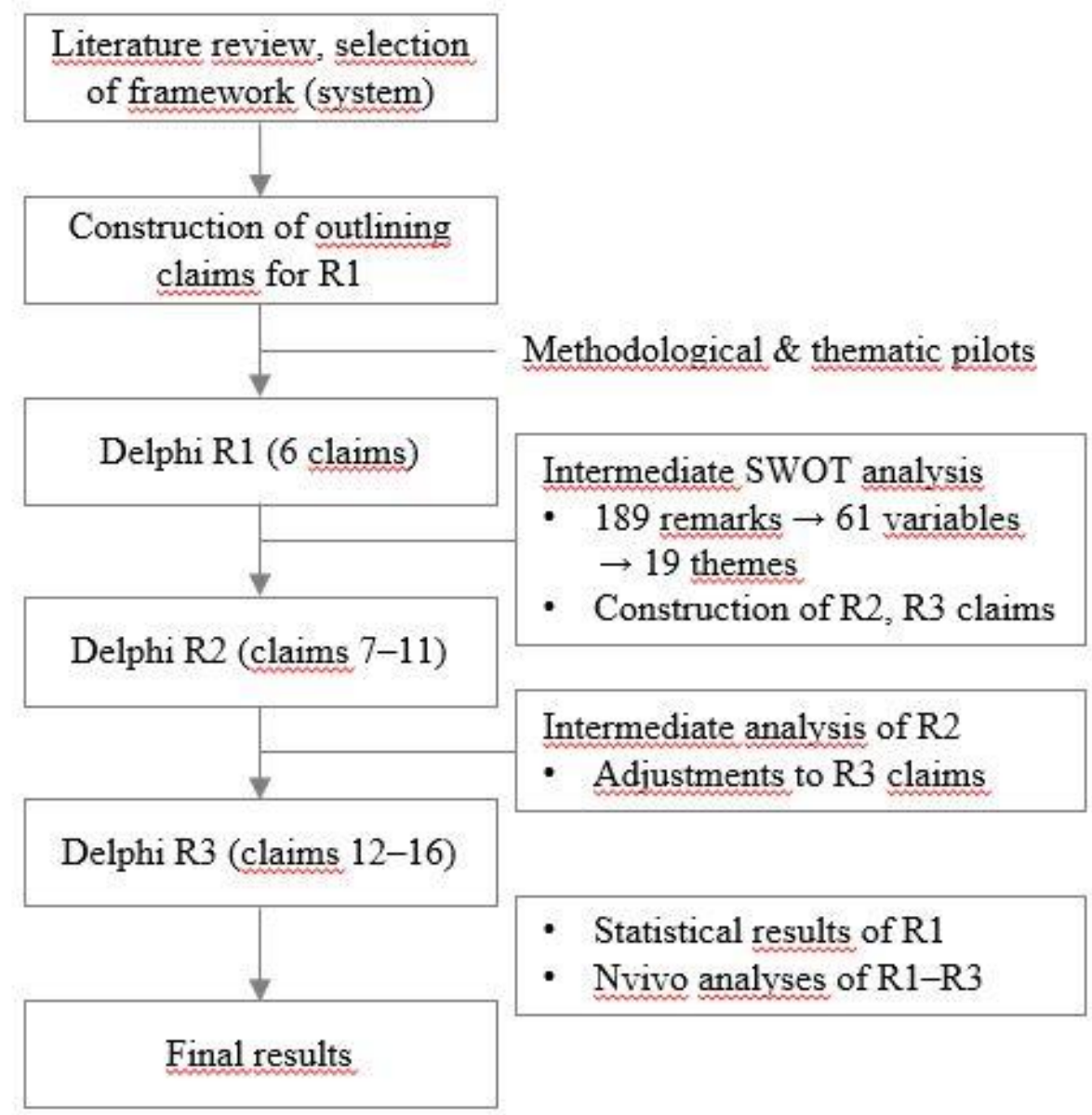

Figure 1. Flow chart of the 3-round, modified Delphi study process.

Before the actual study, R1 was tested twice: first, within an eDelfoi- workshop for comprehensibility and structural clarity and further, regarding the contents by seven test panelists with long experiences in the fields of welfare service execution, research and policymaking. Adjustments and improvements were made after both tests.

R1 of the study consisted of 6 projections for 2030, considering the future of participative welfare policymaking system. The structure of R1 was built based on the theory of expansive learning, developed by an educationalist Yrjö Engeström (1987; 2015). First introduced in 1987, the theory based on the activity theory by psychologist Lev Vygotsky (Engeström, 1995) provides a learning based model for collective development. 


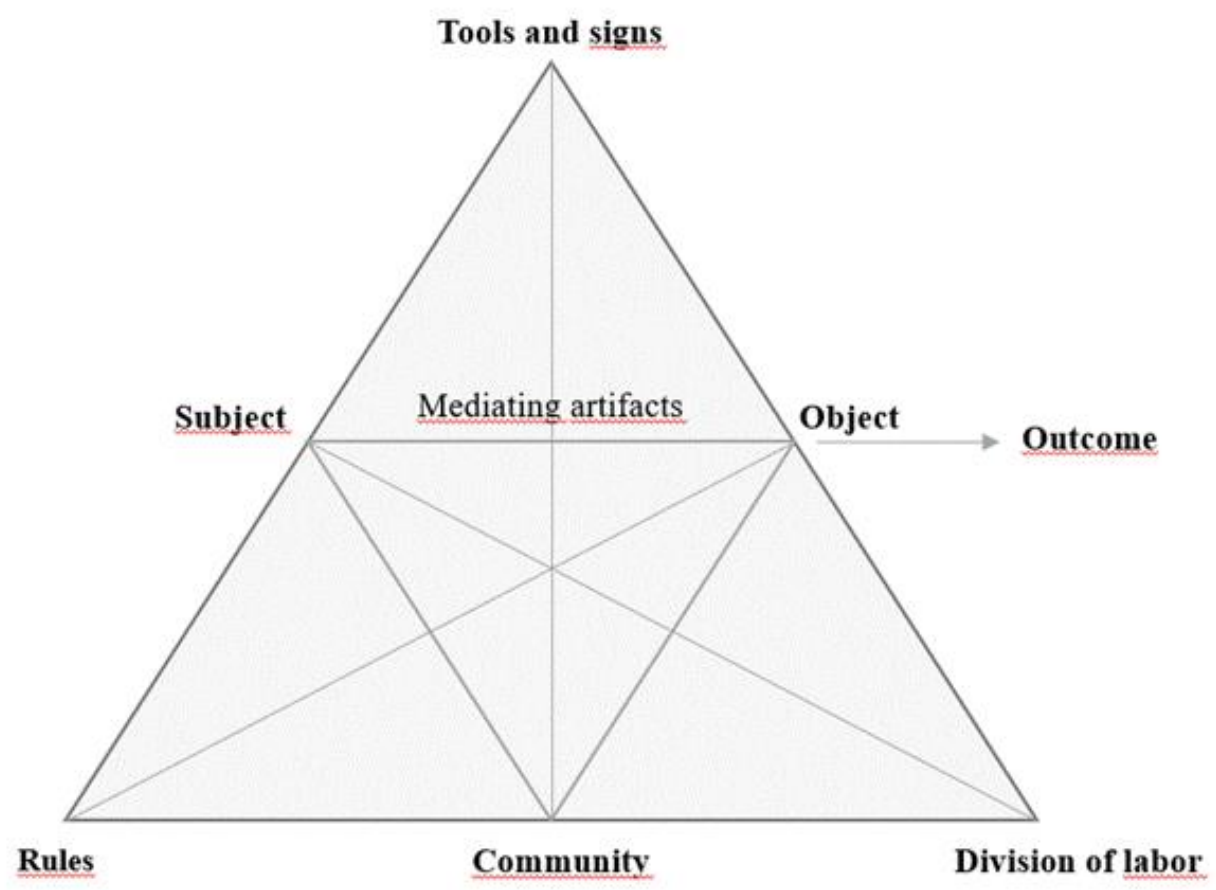

Figure 2. The structure of the human activity system (Engeström 1987: 78)

The Engeström structure of a human activity system (Figure 2.) was selected as a structured framework to study welfare policymaking as a social system. Following reasons supported the use of the framework:

- The "activity" in the human activity system are human interactions within a larger system with a variety of entities, objectives, rules and norms. The activities are studied in real-life practices rather than analyzed knowledge states, detached from the entity. (Jonassen \& Rohrer-Murphy, 1999).

- In the structure, the activity is understood as dynamic and evolutionary, not static nor based on absolute models (Engeström, 2015: 32).

- Activity is analyzed as "contextual or ecological phenomenon" and the model focuses on interactions between the individual and the surrounding environment (Jonassen \& Rohrer-Murphy, 1999; Engeström, 2015: 32-33).

Engeström developed the model originally aiming at illustrating the individual-community relationship and its development in work studies (ibid., xvi), originating from the common grounds and theories with administrative sciences. The model was suitable for the examining of the relationship between the citizens and the municipal welfare policymakers and particularly to elucidate a more general view of its development to build the subsequent rounds of the study.

The basis for the following rounds (R2 and R3) was established during the R1 of the study. Panelists were asked to evaluate the probability and desirability of the claims with a seven-level Likert scale (from $1=$ improbable/undesirable to $7=$ highly probable/desirable) and to give their supportive arguments for each 
evaluation. Panelists were encouraged to debate on each other's remarks as well as to revise their own responses within the timeframe of two weeks. They also received an e-mail notification once there was a comment made on their response in the conversation.

The study was - contrary to the most common types of Delphi-studies - dissent oriented with an objective to bring out the profound welfare policy expert perspectives regarding the development of the citizen participation in welfare policymaking. For the controversies to unfold, the future claims were based on the intentionally accentuated presumption of extensive civic engagement in welfare policymaking in 2030. The claims were built in accordance with the human activity system (above) and the discussion was directed to its constituents, briefly described below. Additional information (e.g. further clarification, statistics and previous research results) and supplementary material (e.g. descriptions of innovative methods in citizen participation) were presented to corroborate and validate each claim.

Claim I/Object: "In 2030, citizens are being extensively heard in welfare policy decisions."

The object is the most significant part of the activity system, extending its problematics over the study and acted on by the subject (Jonassen \& Rohrer-Murphy, 1999). Here, the object of a system is appointed as problematic issues in welfare services, typically characterized by wickedness and high complexity. Behind the concept of wicked problems lies definition developed by design theorists Rittel and Webber (1974). Opposite to tame problems, the solution of a wicked problem requires generating of innovative methods to engage citizens in decisions made to address even challenging ethical problems in society (e.g. Yankelovich 2015).

Claim II/Subject: "In 2030, the users of welfare services function as policy decision-makers equal to officebearers and elected officials."

The subject of the activity is a collective subject, acting on the object (Engström, 2015, p.122; Jonassen \& Rohrer-Murphy, 1999). There is an inherent paradox in outlining participants involved in a decision-making process: growing of the number of participants with the diversity of roles and backgrounds simultaneously increases the complexity of the problem, while it is also a prerequisite for collective awareness (i.a. Conklin 2006: 23-30; Stoppelenburg \& Vermaak 2009). In order to find sustainable solutions and a collective approach to a complex issue, it is crucial to contemplate it from multiple perspectives.

Claim III/Tools: "In 2030 the current, dual decision-making model is replaced by various and diverse processes of decision making."

In this section different tools of policymaking are reflected upon and conventional (usually board based) structures are questioned. In the background of the claim lies a view of adaptable models of decisionmaking in approaching varying problems and focus groups. For example: as an answer to an increasing demand for communality among the youth, social media and various sorts of youth councils could be exploited (Möttönen 2012: 28-29). 
Claim IV/Rules: "In 2030, the hearing of citizens' juries or service user councils is mandatory and centrally supervised."

This claim argues that the existing practices of representative democracy and bureaucratic administration have created their own pitfalls. With an aim to strengthen the legitimacy of the administration by laws, regulations and different established modi operandi, possibilities to react to societal changes can be time consuming and limited, whereas the modernization of society requires prompt responses to changing (welfare) needs and open discussion about a fair distribution of limited resources. (Möttönen \& Kettunen 2011: 384-285.)

Claim V/Community: "In 2030, the welfare policies are made rising above organizational boundaries."

The two last claims of R1 analyze possibilities to reshape the current model of municipal decision making and to transcend the organizational and administrative limits. An individual's engagement to a subject under decision can be formed by geographical or functional interests, latter being criticized for being a threat to residence based representative democracy due to the possibility of uneven distribution of power (Sørensen, 1998). Therefore, it is crucial to define the principle of equality when involving participants in decision making on grounds of functional interests: everyone engaged should have an equal opportunity to be involved in policymaking. At its best, decisions are made in a practical combination of geographical and functional democracy. (Ibid.). Increasingly complex societal issues call for a new, holistic, and constantly developing approach in organizational governing and cooperation (Clarke \& Stewart, 2000).

Claim VI/Division of labor: "In 2030, the welfare policy decisions are serving more community's wellbeing than party politics."

Ambition behind an administrative apparatus is often characterized by its (politicized) protection of achieved position and power, which is rarely perceived as an advance for open and citizens engaging practices (e.g. Vartola, 2005, pp. 98-104). In this claim, the traditional representative system with its political tensions is viewed as a possible inhibitor to the development of the PPM. Behind this claim is an assumption that there should be a transition from politically regulated functioning to a guidance-minded steering based on the mutual respect of different stakeholders in the system, regardless of political activity (Möttönen, 2012, pp. 14-17).

\section{The results of the first round}

The basic principles of a SWOT-analysis were utilized in analyzing and structuring 189 qualitative statements to 61 variables and further to 19 themes (Table 1.). R1 conversation embraced both current attributes and future prospects of the PPM that were further categorized as positive (enabling elements and favourable prospects) and negative (inhibiting conditions and unfavourable consequences). 
Table 1. The results of R1 with number of comments.

\begin{tabular}{|c|c|}
\hline enabling elements (26) & inhibiting conditions ( 86 ) \\
\hline \multicolumn{2}{|c|}{$\begin{array}{l}\text { Factors affecting the progression of the participative policymaking practices. Reflecting the current system, partly } \\
\text { controllable by present-day skills or circumstances. }\end{array}$} \\
\hline Technological skills and web coverage (11) & Unfamiliarity with participative practices (30) \\
\hline $\begin{array}{l}\text { Opportunities in municipal or legislative readjustment } \\
\text { (in reference to the reform) (7) }\end{array}$ & Cultural inertia (24) \\
\hline $\begin{array}{l}\text { Strong (existing) representative system and incipient } \\
\text { hearing practices (6) }\end{array}$ & $\begin{array}{l}\text { Challenges in incorporating participative practices } \\
\text { with current representative system (15) }\end{array}$ \\
\hline \multirow[t]{2}{*}{ Experimental courage (2) } & $\begin{array}{l}\text { Increasing inequality and consumerism in welfare } \\
\text { services (14) }\end{array}$ \\
\hline & $\begin{array}{l}\text { Challenges in municipal readjustment or governing } \\
\text { structures in general (3) }\end{array}$ \\
\hline \multicolumn{2}{|l|}{ favorable prospects (45) } \\
\hline \multicolumn{2}{|c|}{$\begin{array}{l}\text { Resultans of the progression of the participative policymaking practices. Associated with the future development, } \\
\text { partly nebulous or intangible. }\end{array}$} \\
\hline Improvement of legitimacy (18) & Socieltally poor decisions (12) \\
\hline More equitable and flexible resource distribution (21) & Tokenistic participation (8) \\
\hline Regenerating the council work modi operandi (2) & Unequal inclusion (7) \\
\hline Increasing of the health empowerment (2) & Eroding liability for the policies (4) \\
\hline $\begin{array}{l}\text { Improvement in coping with complex welfare policy } \\
\text { issues (2) }\end{array}$ & The decline in political representativeness (1) \\
\hline
\end{tabular}

Considering the first research question, the factors affecting the development of PPM, concerning current administrative attributes, distinct themes stood out in the results of R1:

- technological skills and opportunities in the ongoing Finnish welfare reform as enabling elements, and

- cultural stagnation and the unfamiliarity with participative practices, as well as the challenges in PPM integration into current, representative system as inhibiting conditions.

- The increasing inequality and consumerism were brought forward as the inhibitors of PPM development.

The future prospects of the PPM development and novel, inclusive practices were mostly seen as an improvement to the decision-making legitimacy and equity in service distribution, whereas tokenism and inequality as well as the low quality of policies were seen as unfavourable consequences of the participative practices. 
Despite the emphasis on the qualitative, discursive part of the study, some interesting features in the statistics of the quantitative data (Table 2.) of R1 can be perceived:

Table 2. The statistics of R1

Claim I: In 2030, citizens are being extensively heard in welfare policy decisions.

$(\mathrm{N}=29 / 34) \quad$ Estimates of probability

\begin{tabular}{|c|c|c|c|c|c|c|}
\hline \multicolumn{3}{|c|}{ Estimates of probability } & & \multicolumn{3}{|c|}{ Estimates of desirability } \\
\hline Mean & SD & IQR & M-diff & $\overline{\text { Mean }}$ & SD & IQR \\
\hline 3,79 & 1,236 & 2,00 & 1,38 & 5,17 & 1,197 & 1,00 \\
\hline
\end{tabular}

Claim II: In 2030, the users of welfare services function as policy decision-makers equal to officebearers and elected officials.

\begin{tabular}{|c|c|c|c|c|c|c|}
\hline Mean & SD & IQR & M-diff & Mean & SD & IQR \\
\hline 3,14 & 1,302 & 2,00 & 0,69 & 3,83 & 1,671 & 3,00 \\
\hline
\end{tabular}

Claim III: In 2030 the current, dual decision making model is replaced by various and diverse processes of decision making.

$(\mathrm{N}=28 / 30) \quad$ Estimates of probability $\quad$ Estimates of desirability

\begin{tabular}{|c|c|c|c|c|c|c|}
\hline Mean & SD & IQR & M-diff & Mean & SD & IQR \\
\hline 3,50 & 1,262 & 1,00 & 0,54 & 4,04 & 1,598 & 2,00 \\
\hline
\end{tabular}

Claim IV: In 2030, the hearing of citizens' juries or service user councils is mandatory and centrally supervised.

$(\mathrm{N}=29 / 34)$ Estimates of probability $\quad$ Estimates of desirability

\begin{tabular}{|c|c|c|c|c|c|c|}
\hline & & \multirow[b]{2}{*}{ M-diff } & \\
\hline Mean & SD & IQR & & Mean & SD & IQR \\
\hline 3,86 & 1,246 & 2,00 & 0,62 & 4,48 & 1,503 & 1,50 \\
\hline
\end{tabular}

Claim V: In 2030, the welfare policies are made rising above organizational boundaries.

$(\mathrm{N}=28 / 34) \quad$ Estimates of probability $\quad$ Estimates of desirability

\begin{tabular}{|c|c|c|c|c|c|c|}
\hline Mean & SD & IQR & M-diff & Mean & SD & IQR \\
\hline 4,46 & 1,621 & 3,00 & 1,15 & 5,61 & 1,571 & 2,00 \\
\hline
\end{tabular}

Claim VI: In 2030, the welfare policy decisions are serving more community's wellbeing than party politics.

$(\mathrm{N}=28 / 30) \quad$ Estimates of probability $\quad$ Estimates of desirability

\begin{tabular}{|c|c|c|c|c|c|c|}
\hline Mean & SD & IQR & M-diff & Mean & SD & IQR \\
\hline 3,39 & 1,397 & 1,75 & 1,43 & 4,82 & 1,679 & 1,5 \\
\hline
\end{tabular}

$\mathrm{N}$ : numeric estimates given/active panellists by claim; Mean: the mean of the 7 pt. Likert scale estimates (1= improbable/undesirable; $7=$ highly probable/desirable); SD: standard deviation; IQR: Interquartile range; <1,4: strong consensus ; 1,4-1,75: moderate consensus; 1,75-2,1: moderate dissent; >2,1: strong dissent); M-diff: the difference of probability and desirability estimate means

The desirability of 'citizens being extensively heard' and the 'crossing of organizational boundaries' in welfare policymaking were evaluated the highest of the six claims and simultaneously, had notable difference with regard to the estimates for probability. The latter had the strongest dissent among probability estimates while the development of novel decision-making models was highly agreed on. 
Considering both estimates for probability and desirability, the claim of welfare service users to function as equals to current policy-makers in welfare policymaking was met with disapproval, but then again, with dissent.

\section{The construction of the rounds two and three}

The 19 themes from R1 were grouped under three main categories: service outcomes, structures of involvement and administrative configuration. Following the preliminary analysis of R1, new assertions were constructed and presented to the panelists in the second round (R2). This was repeated for the last, third round (R3) (see Figure 1.).A matrix was applied during R2 and R3 to ensure the coverage of all 19 themes in the iterative rounds (Table 3 .)

Table 3. The coverage matrix of the iterative rounds.

1st round analysis

\begin{tabular}{|c|c|c|c|c|c|c|c|c|c|c|c|c|c|c|c|c|c|c|c|}
\hline \multirow{3}{*}{$\begin{array}{l}\text { Iteration of the R1 themes } \\
\text { in R2 and R3 }\end{array}$} & \multicolumn{19}{|c|}{189 comments $\rightarrow 61$ variables $\rightarrow 19$ themes } \\
\hline & \multicolumn{4}{|c|}{$\begin{array}{l}\text { enabling } \\
\text { elements }\end{array}$} & \multicolumn{5}{|c|}{$\begin{array}{l}\text { inhibiting } \\
\text { conditions }\end{array}$} & \multicolumn{5}{|c|}{$\begin{array}{l}\text { favorable } \\
\text { prospects }\end{array}$} & \multicolumn{5}{|c|}{$\begin{array}{c}\text { unfavorable } \\
\text { consequenses }\end{array}$} \\
\hline & 1 & 2 & 3 & 4 & 5 & 6 & 7 & 8 & 9 & 10 & 11 & 12 & & & 5 & 6 & 17 & 8 & 19 \\
\hline \multirow{3}{*}{$\begin{array}{l}\text { Service outcomes } \\
(\text { claims } 7,9,10)\end{array}$} & & & $\mathrm{x}$ & & & & $\mathrm{x}$ & & & & $\mathrm{x}$ & & & & & & & $\mathrm{x}$ & \\
\hline & & & & $\mathrm{x}$ & $\mathrm{x}$ & $\mathrm{x}$ & $\mathrm{x}$ & & & $\mathrm{x}$ & $\mathrm{x}$ & & & & & & & & $\mathrm{x}$ \\
\hline & & & $\mathrm{x}$ & & & & $\mathrm{x}$ & & $\mathrm{x}$ & & $\mathrm{x}$ & & & & & & & & \\
\hline \multirow{3}{*}{$\begin{array}{c}\text { Structures of } \\
\text { involvement } \\
\text { (claims 11, 13, 14) }\end{array}$} & & $\mathrm{x}$ & $\mathrm{x}$ & & & & $\mathrm{x}$ & & $\mathrm{X}$ & $\mathrm{x}$ & & $\mathrm{x}$ & & & $\mathrm{X}$ & $\mathrm{x}$ & $\mathrm{x}$ & & $\mathrm{x}$ \\
\hline & $\mathrm{x}$ & & $\mathrm{x}$ & & $\mathrm{x}$ & & & $x$ & $\mathrm{x}$ & & & $\mathrm{X}$ & & & & & $\mathrm{x}$ & & \\
\hline & & & $\mathrm{x}$ & $\mathrm{X}$ & & $\mathrm{x}$ & & $\mathrm{x}$ & $\mathrm{x}$ & $\mathrm{x}$ & & & & & & $\mathrm{x}$ & & & \\
\hline \multirow{4}{*}{$\begin{array}{c}\text { Administrative } \\
\text { configuration } \\
\text { (claims } 8,12,15,16)\end{array}$} & & $\mathrm{x}$ & $\mathrm{x}$ & & $\mathrm{x}$ & $\mathrm{x}$ & & $\mathrm{x}$ & $\mathrm{x}$ & $\mathrm{x}$ & & & & & & & & & \\
\hline & $\mathrm{x}$ & $\mathrm{x}$ & $\mathrm{x}$ & & $\mathrm{x}$ & & & & $\mathrm{x}$ & & $\mathrm{X}$ & & $\mathrm{x}$ & & $\mathrm{x}$ & & & $\mathrm{X}$ & \\
\hline & & & $\mathrm{x}$ & & & $\mathrm{x}$ & & $\mathrm{x}$ & $\mathrm{X}$ & & $\mathrm{X}$ & & & & & & & $\mathrm{x}$ & \\
\hline & & & $\mathrm{x}$ & & & & $\mathrm{x}$ & & $\mathrm{x}$ & $\mathrm{x}$ & & & & $\mathrm{z}$ & & & & & \\
\hline
\end{tabular}

R2: chims 7-11; R3: claims 12-16

Before the following rounds, the panelists received a summary of the results from R1. The ten claims of R2 and R3 were built with an objective to clarify the underlying factors affecting the panelists perspectives. The R2 and R3 claims were constructed by variety of questions (e.g. multiple-choice questions and evaluation assignments), all including additional information or reference to timely studies or welfare reform updates. Some statements causing lively responses in R1 were added to elaborate the claims. 


\section{Service outcomes}

The future claims elaborated welfare services by picturing Finland in 2030

- as a welfare state, offering services and benefits under the Scandinavian tenets of universalism;

- with the frames of welfare services provided by public funding established by commonly accepted ethical principles, and

- offering welfare services more equal in comparison with the services prior to the reform.

\section{Structures of involvement}

The future development of enabling structures for involvement was considered by means of policymaking roles in 2030, in which

- citizens/service users are obligated to participate in the evaluation, preparatory work and decisionmaking of the welfare policies;

- an important role of the municipality is to embrace the communality and support the social capital of the (community as a ) "tribe ${ }^{10 ",}$, and

- the regional welfare services are outlined by the elected officials, yet the most complex issues being deliberated in regionally coordinated citizens' juries.

\section{Administrative configuration}

The administrative configurations in 2030 were visualized as

- the municipalities with an altered role (after the reform) emphasizing and promoting well-being and resilient welfare solutions;

- the National Institute for Health and Welfare as a strong normative adviser of the independent regions, and

- the welfare service prioritization coordinated and supervised nationally, in co-operation with various stakeholders (such as the National Advisory Board on Social Welfare and Health Care Ethics, Finnish Medicines Agency) and relative civic statements.

The panelists were also asked to arrange the Finnish welfare service stakeholders in the order of importance in affecting the supply of the welfare services in 2030. Additional, missing stakeholders could be added by the panelists.

\section{Study results}

The preliminary analyses were performed after R1 and R2 to construct the claims for the subsequent round(s). The statistical analysis of R1 quantitative data was conducted by SPSS ${ }^{\circledR}$-software, and a more precise final analysis of the qualitative data was conducted by NVivo 11 Pro $^{\circledR}$-software. The statements were

\footnotetext{
${ }^{10}$ Expression used and discussed by panelists in R1.
} 
classified $^{11}$, numbered ${ }^{12}$ and clustered under three main headings originating from the analysis of R1: 1) service outcomes, 2) the structures of involvement, and 3) administrative configuration. The following summary answering the second research question, is categorized accordingly.

\section{Service outcomes ${ }^{13}$}

The maintaining of equal and universal public services was perceived to have far-reaching consequences to social order, general trust and productivity. On the other hand, the current welfare service system and its administration was commonly seen as rigid to respond to individual needs with distinct and individual, underlying factors. The inability to design individually flexible, yet prioritized frames for the services was construed to have resulted in "profit seeking cost-effectiveness as primary focus on the evaluation of welfare practices". The myopic economic attitude was also reasoned as the corollary of financial unsustainability as well as the increasing economic asymmetry. The ability to influence welfare policies was increasingly linked with wealth and one's ability to pay for private health services.

The call for a definition of "what and how" in public welfare services by means of prioritization and "the novel methods of measuring economic [service] productivity by taking account of human well-being" were widely expressed and supported by the panelists. There was a wide agreement on the unbearableness of the current implementation of the principles of universalism, which were also contested as merely symbolic, already eroded by increasing service fees and the insufficiency of current livelihood or services equalizing systems.

\section{The structures of involvement ${ }^{14}$}

The panelists considered increasing administrative - including feedback - transparency, two-way discourse with a variety of coordinated, undemanding methods as prerequisites for advancing citizens' involvement. The need for promoting the participation was understood resulting from the underlying aspiration for a stronger sense of affinity and "community spirit" which, however, cannot be met by obligating the citizens or service users to participate.

However desirable, the objectives of citizen involvement were treated with reservations and even scepticism. Most doubts were expressed about the practical details and the additional resources required to the implementation of citizens' juries, the excessive representation of the already active citizens and the true policy influence of the public opinion. The representativeness of the underprivileged was considered as a significant issue, not able to be met by merely technological or general solutions.

\footnotetext{
${ }^{11}$ Comments referring to personal healthcare service decisions (e.g. decisions of medical treatments by the healthcare professio nals) were excluded from the analysis.

12 The numbering of the statements (claim N/statement $\mathrm{N}$ ) enabled the verification of the statement interpretation during the confirmatory assessment.

1374 clustered statements of the claims 7,9 and 10 (service outcomes)

${ }^{14} 60$ clustered statements of the claims 11,13 and 14 (the structures of involvement)
} 
Doubts were also stated regarding some civic aptitudes, assumed to be required for the engagement, such as subjectivity, willingness to participate, discursive skills and abilities to assimilate the municipal "big picture". The shortages in participative skills were alternatively expressed as developmental targets and to be met by "strengthening the citizens' abilities to influence [the decision-making]" by means of carefully constructed processes.

\section{Administrative configuration ${ }^{15}$}

The changing role of the municipalities (from the provision of healthcare services to the promoting of well-being, due to the ongoing reform) was generally perceived as positive. It was, for example, seen as an opportunity for the municipalities to "take an active role in the cooperation with voluntary associations" and universities. In order to achieve the requirements of the new role, the panelists called for sufficient resources to meet the needs of proactivity, as well as the increasing guidance of the ministries and the National Institute for Health and Welfare (THL) in supporting the municipal, regional and NGO service development and evaluation.

National proposals for the welfare services prioritization were anticipated, rather than leaving the deliberation in the regions, municipalities or single organizations, all in novel roles due to the reform. The national alignment in prioritization was frequently mentioned as a prerequisite to face the future challenges to maintain service equality, menaced by the privatization of the services, and the growth of the regional - and more distant - policymaking power.

\section{Discussion}

Due to the evolving, multilayered and multi-agency features of complex systems, to formalize a perfect model for a systematic investigation is not possible. This is naturally a wider challenge for social sciences, unable to achieve the repeatable measures used for natural sciences to illustrate - nor to predict - the creative and imperfect evolutionary processes of human systems. Nevertheless, a multi-agent model, even with limitations, creates a most appropriate representation of a complex system. (Allen, 2018.)

The research leaned on the perception of the growing role of public participation in public governance. The shift is scarcely perceptible in documents concerning welfare service planning and reforming in Finland. The Ministry of Social affairs and Health is framing customer orientation in its strategy as "an offset of developing services as well as a strategic choice aimed to shift emphasis towards preventative and achievable care". The welfare service reform was planned to be implemented through "the active participation of service users", assigning, however the communities (municipalities, regions) to determine their means of citizen involvement. The Local Government Act, which enables the municipalities to develop a range of participative activities and regulates the inhabitants' right to take part in them, does not ensure the implementation of the

\footnotetext{
1585 clustered statements of the claims $8,12,15$ and 16 (administrative configuration)
} 
law in local welfare policymaking. This has resulted in miscellaneous modus operandi, highly dependent on local administrative actors' motivation to advance participative strategies and structures (Nurmi, Syväjärvi \& Leinonen, 2018).

The results of the Delphi study show that regardless of strong trust in technological preparedness and the structural opportunities in the extensive Finnish welfare reform previously well in progress, the cultural stagnation and unfamiliarity generate attitudes inhibitory of PPM development. Even though the resultants in advancing the participative practices were considered influential to decision-making legitimacy in general, as well as the very central idea of welfare services, equal and flexible resource distribution, there were reservations about the true inclusion and the implementation of PPM practices. In some responses, the reservations regarding the issue were implied to rise from its assumed juxtaposition of the traditional, representative policymaking and the participative policymaking practices.

Several undercurrents affecting the development of PPM were discernible in the conversations. Proliferating consumerism in welfare services in tandem with the public funding insufficiency were emphasized, collectively proliferating general inequality and individualism. Put in the systemic frame of the study construction, the results show a notorious, vicious cycle: fiscal limitations and economic restrictions leading to myopic service decisions, increasing the service inequality and further, social inequality and therefore, the increasing need for services. Wilkinson \& Pickett (2010, pp. 190-196), basing on the findings of inequalities causing widespread negative effects beyond income levels, highlight more fundamental causality between the nations' ideological change and well-being of the citizens, inequality functioning as a major denominator of difficulties connecting to social status and having therefore wider and corrosive effects on the society. EspingAndersen (2005) approaches the mutual causality of the two: "If, as is possible, we are dealing with a chickenand-egg problem, this may not matter from a public policy point of view because, in this case, a reduction of inequality on either of the two dimensions ought to have positive effects on the other".

The complex issue of policymaking participation becomes even more complex considering the disadvantaged falling short of rates of activity (e.g. Verba, Lehman Schlozman \& Brady, 2002, pp. 511-513). Various and comprehensive studies underline the importance of structural, social cohesion on civic engagement: higher the level of income inequality, the higher the range of social issues and lower the rate of participation and development of common interest (Acik-Toprak 2009: 204-205). Arguments for participatory decisionmaking highlight the socially equalizing outcomes of involvement (Clawson \& Oxley, 2017, p.10). Macpherson (1977, p. 94) described this ethical requirement: "This is not to say that a more participatory system would of itself remove all the inequities of our society. It is only to say that low participation and social inequity are so bound up with each other that a more equitable and humane society requires a more participatory political system."

It is stated that the past Finnish health care reforms have so far failed to meet their objectives due to the disconnection between issues addressed and the challenges of the society (Vartiainen 2010). According to 
this research, the clear signals of weakening universalism and equality - the very essence of the Nordic welfare system - have harmful effects on the development of participative practices in welfare service policymaking and yet, diminishing of these values creates a demand for an open dialogue of our welfare policies.

\section{Implications}

- In order to advance the complex welfare systems' abilities to create holistic and more societally responsive and adaptive policies, the views of the service users need to be made explicit.

- The cultural stagnation and unfamiliarity of advantages achieved by citizens' engagement generate attitudes inhibitory of participative policymaking development. It is noteworthy to emphasize the mutual supportive effects of participative and traditional, representative policymaking practices.

- The socially equalizing outcomes of involvement can enhance the communal ability to achieve a more systemic view of a complex entity of the societal well-being. This requires creation and establishment of the participative arrangements, as well as ongoing discourse between policymaking establishments, voluntary organizations, community groups and the research institutes.

\section{References}

Acik-Toprak, N. (2009) Civic Engagement in Europe: A Multilevel Study of the Effect of Individual and National Determinants on Political Participation, Political Consumerism and Associational Involvement. University of Manchester. Faculty of Humanities. Doctoral thesis. Retrieved from: https://www.escholar.manchester.ac.uk/api/datastream?publicationPid=uk-ac-man-scw:94093\&data streamId=FULL-TEXT.PDF.

Adams, D., \& Wiseman, J. (2003). Navigating the future: a case study of Growing Victoria Together. Australian Journal of Public Administration, 62(2), 11-23.

Allen, P. (2018). Complex evolving social systems: unending, imperfect learning. In E. Mitleton-Kelly, A. Paraskevas \& C. Day (Eds.), Handbook of research methods in complexity science: Theory and applications (pp. 18-44). Cheltenham: Edward Elgar Publishing, Inc.

Appadurai, A. (2013). The future as cultural fact: Essays on the Global Condition. London: Verso.

Atkinson, R. (2002). The white paper on European governance: implications for urban policy. European Planning Studies, 10(6), 781-792.

Blue, G. (2018). Scientism: A problem at the heart of formal public engagement with climate change. $A C M E$ $17(2), 544-560$.

Boulton, J.G., Allen, P.M. \& Bowman, C. (2015). Embracing Complexity : Strategic Perspectives for an Age of Turbulence. $1^{\text {st }}$ edition. Oxford: Oxford University Press.

Byrne, D. (2001). Complexity theory and the social sciences: An introduction (2 ${ }^{\text {nd }}$ ed.). London: Routledge. 
Cairney, P. (2012). Complexity theory in political science and public policy. Political Studies Review 10(3), 346-358.

Capra, F. \& Luisi, P.L. (2014). The Systems View of Life : A Unifying Vision. Cambridge: Cambridge University Press.

Clarke, M. \& Stewart, J. (2000). Handling the Wicked Issues. In C. Davies, L. Finlay \& A. Bullman (Eds.), Changing Practice in Health and Social Care (pp.377-386). London: Sage.

Clawson, R.A. \& Oxley, Z.M. (2017). Public Opinion: Democratic Ideals, Democratic Practice. London: SAGE Publications Ltd.

Collins, B. (2010). Energy, Transport, Environment and the Policy Challenge. E:CO Emergence: Complexity and Organization, 12(2), 77-80.

Conklin, E. J. (2006). Dialogue Mapping: Building Shared Understanding of Wicked Problems. Hoboken, NJ : Wiley.

Dalkey, N., \& Helmer, O. (1963). An experimental application of the Delphi method to the use of experts. Management science, $9(3), 458-467$.

Dennard, L. F., Richardson, K. A. \& Morçöl, G. (2008). Editorial. In L. F. Dennard, K. A. Richardson \& G. Morçöl (Eds.), Complexity and policy analysis: Tools and methods for designing robust policies in a complex world (pp. 1-22). Goodyear, AZ: ISCE Publishing.

Engeström, Y. (1987). Learning by expanding: An activity-theoretical approach to developmental research. Helsinki: Orienta-Konsultit.

Engeström, Y. (2001). Expansive learning at work: Toward an activity theoretical reconceptualization. Journal of education and work, 14(1), 133-156.

Engeström, Y. (2015). Learning by expanding: An activity-theoretical approach to developmental research ( $2^{\text {nd }}$ ed.). New York, NY: Cambridge University Press.

Eppel, E. (2012). What does it take to make surprises less surprising? The contribution of complexity theory to anticipation in public management. Public Management Review 14(7), 881-902.

Eppel, E. (2017). Complexity thinking in public administration's theories-in-use. Public Management Review $19(6), 845-861$.

Eriksson, M. \& Lindström, B. (2014). The salutogenic framework for well-being: implications for public policy. In T. J. Hämäläinen \& J. Michaelson (Eds.), Well-being and beyond: Broadening the Public and policy discourse (pp. 68-97). Cheltenham: Edward Elgar Publishing Ltd.

Esping-Andersen, G. (2005). Inequality of incomes and opportunities. In A. Giddens \& P. Diamond (Eds). The New Egalitarianism (8-38). Cambridge: Polity Press.

Eurocientist (2016). Bringing RRI forward. Retrieved from http://www.euroscientist.com/bringing-rri-forward/.

Goergen, M., Mallin, C., Mitleton-Kelly, E. Al-Hawamdeh, A. \& Chiu, I. H-Y. (2010). Corporate governance and complexity theory. Cheltenham: Edward Elgar Publishing Ltd.

Haynes, P. (2015). Managing complexity in the public services ( $2^{\text {nd }}$ ed.) London: Routledge.

Hemerijck, A. (2002). The self-transformation of the European social model(s). In G. Esping-Andersen, D. Gallie, A. Hemerjick \& J. Myles (Eds.), Why we need a new welfare state (pp. 173-213). OUP Oxford. 
Hiltunen, E. (2011). Crowdsourcing the future: the foresight process at Finpro. Journal of Futures Studies, 16(1), 189-196.

Kernick, D.P. (2008). Facilitating resource decision making in public organizations drawing upon insights from complexity theory. In L. F. Dennard, K. A. Richardson \& G. Morçöl (Eds.), Complexity and policy analysis: Tools and methods for designing robust policies in a complex world (pp. 105-115). Goodyear, AZ: ISCE Publishing.

Kuntaliitto (n.d.). Retrieved from https://www.kuntaliitto.fi/tilastot-ja-julkaisut/kaupunkien-ja-kuntien-lukumaarat

Kuusi, O. (2002). Delfoi -menetelmä. [The Delfoi-method.] In M. Kamppinen, O. Kuusi \& S. Söderlund (Eds.), Tulevaisuudentutkimus: Perusteet ja sovellukset [Futures research: Foundations and directions] (pp. 204-225). Helsinki: Suomalaisen Kirjallisuuden Seura.

Köhler, J., Wendling, C., Addarii, F., Grandjean, M., \& Wilkinson, A. (2015). Concurrent Design Foresight. Report to the European Commission of the Expert Group on Foresight Modelling. Luxembourg: Publications Office of the European Union.

Linstone, H. A., \& Turoff, M. (1975). The delphi method (pp. 3-12). Reading, MA: Addison-Wesley.

Linturi, H. (2007). Delfoin metamorfooseja. [The metamorphoses of Delfoi.] Futura 26(1).

Linturi, H. \& Rubin, A. (2014). Metodi, metafora ja tulevaisuuskartta. [The method, metaphor and the future map]. Futura 33(3).

Mannermaa, M. (1988). Complexity and systems thinking in futures research: From "neutral" scenarios to value considerations. Systems Practice 1(3), 279-205.

Macpherson, C.B. (1977). The Life and Times of Liberal Democracy. Oxford: Oxford University Press.

Ministry of Finance (2017). Open Government III Action Plan 2017-2019 Finland. Retrieved from https://www.opengovpartnership.org/sites/default/files/Finland_NAP_2017-2019_EN.pdf.

Ministry of Finance (2018). Open Government Partnership. National Action Plan - Finland 2017-2019:

Mid-term interim evaluation. Retrieved from https://avoinhallinto.fi/assets/files/2018/09/In-English_OGP_Self-assessment_Finland_Midterm2017_2019-FINAL.pdf.

Mitleton-Kelly, E. (2003). Ten principles of complexity and enabling infrastructures. In E. Mitleton-Kelly (Ed.), Complex systems and evolutionary perspectives on organisations: The application of complexity theory to organisations, 1, 23-50.

Mitleton-Kelly, E. (2011a). Identifying the multi-dimensional problem-space and co-creating an enabling environment. Emergence: Complexity and Organization, 13(1/2), 1-25.

Mitleton-Kelly, E. (2011b). A complexity theory approach to sustainability: A longitudinal study in two London NHS hospitals. The Learning Organization 18(1), 45-53.

Möttönen, Sakari \& Pekka Kettunen (2011). Yksilöosallistuminen ja yhteisöosallistuminen kuntien hyvinvointipalveluissa: Pohdintaa taustoista, periaatteista, vahvuuksista ja heikkouksista. [Individual participation and community participation in municipal welfare services: Reflection on backgrounds, principles, strengths and weaknesses.] Kunnallistieteellinen aikakauskirja 39: 3, 281-293.

Möttönen, S. (2012). Kunnan poliittisen johtamisen uudistaminen - kokemuksia, näkemyksiä ja ehdotuksia. [Reshaping the political leadership in municipalities - experiences, perceptions and proposals.] Helsinki: Suomen Kuntaliitto. 
Nurmi, H., Syväjärvi, A. \& Leinonen, J. (2018). Osallistava toimintaote hyvinvoinnin edistämistyössä. [Participatory manners in the advancement of well-being.] In J. Lammintakanen \& S. Laulainen (Eds.), Towards sustainable decision-making and management in welfare services (pp. 113-126). Kuopio: University of Eastern Finland.

Parsons, W. (2004). Not just steering but weaving: Relevant knowledge and the craft of building policy capacity and coherence. Australian journal of public administration, 63(1), 43-57.

Pernaa, H-K. (2017). Deliberative future visioning: utilizing the deliberative democracy theory and practice in futures research. European Journal of Futures Research, 5(1), 1-10.

Perttola, L. \& Pernaa, H-K. (2016). The Absent Minority in Welfare Planning: Entitling or Overburdening Citizens with Responsibility? Social Research 39(2), 48-61.

Pierson, P. (2000). Three worlds of welfare state research. Comparative Political Studies, 33(6/7), 791-821.

Pyun, H. O., \& Gamassou, C. E. (2018). Looking for Public Administration Theories? Public Organization Review, 18(2), 245-261.

Raisio, H. (2009). Health care reform planners and wicked problems: Is the wickedness of the problems taken seriously or is it even noticed at all? Journal of Health Organization and Management 23(5), 477493.

Raisio, H. (2010). The public as policy expert: Deliberative democracy in the context of Finnish health care reforms and policies. Journal of Public Deliberation 6(2), article 6.

Raisio, H., Valkama, K. \& Peltola, E. (2014). Disability and deliberative democracy: towards involving the whole human spectrum in public deliberation. Scandinavian Journal of Disability Research, 16(1), 77-97.

Rask, M. T., Mačiukaitė-Žvinienė, S., Tauginienè, L., Dikčius, V., Matschoss, K. Aarrevaara, T. \& d'Andrea, L. (2016). Innovative Public Engagement: A Conceptual Model of Public Engagement in Dynamic and Responsible Governance of Research and Innovation. Retrieved from https://pe2020.eu/wp-content/uploads/2016/05/Innovative-Public-Engagement-FINAL.pdf.

Rask, M., Puustinen, A. \& Raisio H. (2018). Toward a theory of fourth sector involvement. Paper presented in ECPR conference, Hamburg 22-25 August. Retrieved from https://ecpr.eu/Filestore/PaperProposal/5dc86a23-35c9-4cee-8090-5a3c84c9b8a6.pdf.

Rieger, W. G. (1986). Directions in Delphi developments: Dissertations and their quality. Technological Forecasting and Social Change, 29(2), 195-204.

Riikonen, E., Makkonen, M., Smith, G. (2004). Good Marginality? In V. Puuronen, A. Häkkinen, A. Pylkkänen, T. Sandlund \& R. Toivanen, R. (Eds). New Challenges for the Welfare Society (311325). Publications of Karelia Institute. Joensuu: University of Joensuu.

Rittel, H. W., \& Webber, M. M. (1974). Wicked problems. Man-made Futures, 26(1), 272-280.

Seaford, C. (2014). What implications does well-being science have for economic policy? In T. J. Hämäläinen \& J. Michaelson (Eds.), Well-being and beyond: Broadening the Public and policy discourse (pp. 221243). Cheltenham: Edward Elgar Publishing Ltd.

Sørensen, E. (1998). New forms of democratic empowerment: Introducing user influence in the primary school system in Denmark. Statsvetenskaplig Tidskrift 101(2), 129-143.

Spicker, P. (2008). Social policy: Themes and approaches ( $2^{\text {nd }}$ ed.). Bristol: The Policy Press. 
Stoppelenburg, A. \& Vermaak H. (2009). Defixation as an Intervention Perspective: Understanding Wicked Problems at the Dutch Ministry of Foreign Affairs. Journal of Management Inquiry 18(1), 40-54.

THL (2019). National Institute of Health and Welfare. Retrieved from https://thl.fi/en/web/social-welfareand-health-care-reform.

Vartiainen, P. (2005). Wicked health care issues: An analysis of Finnish and Swedish health care reforms. In G.T. Savage, J.A. Chilingerian, M. Powell \& Q. Xiao (Eds.), International Health Care Management. Advances in healh care management (pp.159-182). Bingley: Emerald Group Publishing Limited.

Vartiainen, P. (2010). Changes and challenges in Finnish health care management. Society and Economy $32(1), 123-136$.

Vartola, J. (2005). Näkökulmia byrokratiaan. [The perspectives of byrocracy.] Tampere: University of Tampere.

Verba, S., Lehman Schlozman, K. \& Brady, H.E. (2002). Voice and equality: Civic voluntarism in American politics. 4th printing. Cambridge: Harvard University Press.

Warren, M. E. (2009). Governance-driven democratization. Critical policy studies, 3(1), 3-13.

Ziglio, E. (1996). The Delphi method and its contribution to decision-making. In M. Adler \& E. Ziglio (Eds.). Gazing into the Oracle: The Delphi method and its application to social policy and public health, 5. (pp. 3-33.) London: Jessica Kingsley Publishers.

Yankelovich, D. (2015). Wicked problems, workable solutions: Lessons from a public life. London: Rowman \& Littlefield. 